\title{
Identification of productive systems of beef cattle in the northwest Region of Paraná, Brazil
}

\section{Identificação dos sistemas produtivos de bovino de corte da Região Noroeste do Paraná, Brasil}

\author{
Cecilia Menchon Tramontini ${ }^{1 *}$; Rejane Machado Cardozo²; \\ Jailson de Oliveira Arieira ${ }^{3}$
}

\begin{abstract}
The purpose of this paper is to identify beef cattle production systems in the northwestern part of the state of Paraná, Brazil. To achieve this, interviews with 42 randomly selected cattle breeders were conducted between the months of November and December 2016 to describe the reality of the farms of this region. These interviews were carried out through a semi-structured questionnaire containing 49 questions pertaining to the reality of farms regarding herd management and property (nutrition, health, reproduction, and animal welfare), environment care, property area, and realized activities. Additionally, this questionnaire described the requirements of slaughterhouse for animal housing and the values obtained by the animals marketed according to the producers. After the interviews were carried out, a data bank was created using the software Microsoft Excel (ver. 2010). The data was later transferred to the software PASW 18 for Windows to perform multivariate statistical analyses. Defining the most representative variables was realizedwith multivariate statistical analysis, and these were represented by factor analysis, cluster analysis, and discriminant analysis to define the production systems. Through statistical analysis, three different systems were defined: the first production system has 18 , the second production system five, and the third production system has 18 cattle breeders. The three systems found in the northwest region of the state of Paraná have different production and marketing characteristics, with the second system being superior to the other systems.
\end{abstract}

Key words: Meat. Marketing. Structuring of the Property. Animal Production and Remuneration.

\section{Resumo}

Objetivou-se identificar os sistemas de produção de bovinos de corte existentes no Noroeste do Paraná. Para isso foram entrevistados 42 pecuaristas escolhidos aleatoriamente para retratar a realidade da criação de bovinos na região, entre os meses de Novembro e Dezembro de 2016. Estas entrevistas foram por meio de um questionário semiestruturado contendo 49 questões que retratam a realidade das fazendas sobre o tipo de criação, o manejo da propriedade com os animais, os cuidados ambientais implementados na propriedade, área total e tipo de exploração da propriedade; como também retrata as exigências dos frigoríficos para as carcaças dos animais e os valores obtidos pelos animais comercializados segundo os produtores. Após a coleta, foi realizada a tabulação dos dados obtidos no programa Microsoft

1 M.e, Programa de Pós-Graduação em Produção Sustentável e Saúde Animal, Universidade Estadual de Maringá, UEM, Centro de Ciências Agrárias, CCA, Umuarama, PR, Brasil. E-mail: ceciliatramontini@gmail.com

2 Prof $^{\mathrm{a}}$ Dr $^{\mathrm{a}}$, Programa de Pós-Graduação em Produção Sustentável e Saúde Animal, UEM, CCA, Umuarama, PR, Brasil. E-mail: rmcardozo@uem.br

3 Dr., Administrador e Consultor, ATTA Consultores Associados Ltda., ATTA, Umuarama, PR, Brasil. E-mail: jarieira@ attaconsultores.com.br

* Author for correspondence 
Excel $2010^{\circledR}$ para, então serem realizadas as análises multivariadas no pacote estatístico PASW 18 para Windows. Foram definidas as variáveis mais representativas para então serem realizadas as analises multivariadas, sendo as mesmas representadas pela Análise de Fatores, Análise de Agrupamento e Análise Discriminantes. A partir das análises os sistemas foram identificados como três grupos distintos de produção, o primeiro sistema é composto por 18 produtores, o segundo sistema por cinco produtores e o terceiro sistema constituído por 18 produtores. Os três sistemas possuem características de produção e comercialização diferentes entre si, porém, o sistema 2 mostrou-se superior aos demais. Portanto, na região Noroeste do Paraná existem três sistemas distintos de produção de bovinos de corte sendo o sistema 2 superior aos demais sistemas de produção.

Palavras-chave: Carne. Comercialização. Estruturação da Propriedade. Produção Animal e Remuneração.

\section{Introduction}

In socioeconomic terms, cattle farming is one of the most important activities in the Brazilian agribusiness since it is widely developed in the national territory, with diversity of breeds and their crossbreeding, as well as production systems and marketing strategies based on the situation of each region and where its production is headed (FERNANDES et al., 2015). In 2015, Brazil reached a record number of cattle heads, accounting to 474,4 million units. The Midwest region supplied $33.8 \%$ of the country's production; therefore, it was the region with the highest number of cattle heads. In this year, there has been an increase in the North, Midwest, and Southeast region. The Southern region did not display growth, but it maintained a steady cattle herd. Only the Northeast region experienced a decrease in numbers (IBGE, 2016; PORTAL BRASIL, 2016).

With an increase in the population and its purchasing power, consumption and demand for meat have been increasing, especially in developing countries such as Brazil, China, India, and Russia. Because Brazil has a vast territory and a tropical climate, the country has a vocation and potential for beef production and it can meet the high demand for this product. Brazil has reached a prominent position in the cattle market on a global scalesince it has the largest commercial herds. Besides, it is thought to be the world's second largest producer; for this reason, cattle farming has been gaining ground compared to animal production (FERRAZZA et al.,

\section{3; FERRAZZA et al., 2015; HOFFMANN et al.,} 2014).

Because cattle is mostly bred in pastures, it could be inferred that the animal nutrition cost in the country is low because those animals have native or cultivated tropical grasses as their main source of nutrients, without many expenses related to management and fertilization. Consequently, pastures are to be regarded as a fundamental component of the animal production system. Its use is advised in a sustainable way due to its high nutritional contribution to ruminants (HOFFMANN et al., 2014).

Since production and termination of animals is in the pasture, Brazilian cattle farming is known for the slaughter of older cattle. Changes in the production systems have taken place, especially to improve animal productivity and meat quality. These improvements are obtained from the use of semi-intensive and intensive systems in properties, and the use of industrial crossbreeding among races to reach a reduction of slaughter age. Thus, this factor is essential for boosting and improving the cattle production, because the increase in production generates precocious animals and it increases competitiveness in the internal and external market, especially by increasing the quality of the final product (FERNANDES et al., 2015).

Moreover, livestock are distributed all over the country, which contains a diverse production system. It is essential for the properties to feature planning, 
control, and productive business management (FERRAZZA et al., 2013; FERRAZZA et al., 2015). Considering that the economic return of the rural producer is directly connected to the production scale, the production must be economically analyzed in order to reap benefits from it. The greater the produced volume in a given space of time (the smaller the better), the greater the bargaining power a producer will have when negotiating with cold storage room owners and input suppliers (DEMEU et al., 2012).

Due to the various production systems and livestockand the fact that livestock is a key sector in agribusiness, it is possible that such differences in production systems influence animal production and product end quality.

In conclusion, considering the diversity of production strategies adopted in cattle farming in Northwest Paraná and stressing the importance of this activity for the region because it generates income and employment in the local economy, this study analyzes the different production systems to elucidate what can be done to refine and improve the cattle production of the region, serving as a subsidy for the formulation of public policies for the sector and guidance for farmers, researchers, and extension personnel.

\section{Material and Methods}

\section{Data collection}

This study was performed in the Northwest of Paraná, which consists of 61 municipalities. According to SEAB/DERAL (2015), it is the region containing the largest herds of cattle in the state, amounting to 2,084,593 heads in 2013.

To define the number of cattle farmers to be interviewed, the Department of Rural Economy (DERAL) of the city of Umuarama, which is linked to the Department of Agriculture and Supplies (SEAB), was contacted to inquire about the number of beef cattle slaughtered by municipality in 2015 .
After obtaining these data, the sample size of the study was defined. It was composed of 42 cattlemen using the formula presented by Stevenson (1981) and Milone (2004).

where:

$$
n=\left(z \frac{\sigma_{x}}{e}\right)^{2}
$$

$n=$ sample size to be surveyed;

$z=$ desired degree of confidence $(95 \%)=1.96$;

$e=$ admitted or tolerable error in the analysis ( $30 \%$ of the average of each variable);

$s_{\mathrm{x}}=$ estimated standard deviation of the sample (calculated in the pre-test).

The producers interviewed were randomly chosen to answer a semi-structured questionnaire and produce a representative sample of the situation in Northwest Paraná.

The survey contained 49 questions that cover the type of establishment, property management (food, sanitary, reproductive management, and animal welfare), environmental care implemented in the property, total area, and the type of property exploration. It also depicts the demands of cold storage rooms for animal carcasses and the values obtained by the animals marketed according to the producers.

The interviews were conducted between the months of November and December 2016 during visits to the properties or the farmers' houses. The list of cattle farmers of the region was obtained from the Rural Society of Umuarama and some cattle buyer offices in the city.

After collection, tabulation of data was carried out in Microsoft Excel 2010 ${ }^{\circledR}$, followed by multivariate analyses using PASW 18 statistical package for Windows. According to Corrar et al. (2009), "the multivariate analysis refers to a set of statistical methods that enables a simultaneous analysis of multiple measures for each individual, object, or phenomenon observed" (p. 2). 
Three analysis techniques were employed to identify and define the systems, which are going to be explained further.

\section{Multivariate analysis}

\section{Factor analysis}

Factor Analysis (FA) is a statistical technique employed to identify factors that may be used to explain a relationship between sets of variables. This analysis was employed to reduce the number of variables and to create a specific model for the analysis. After the factors were defined, they were used in the grouping analysis or Cluster (CORRAR et al., 2009).

\section{Grouping analysis}

This analysis was employed using the data obtained by the previous analysis to determine the number of homogeneous farmers in the region of study to group them according to their characteristics. This is an exploratory analysis that aims to group members with certain common and/or similar characteristics (ALEIXO et al., 2007; LOPES JUNIOR et al., 2012; SOTOMAIOR et al., 2007).

\section{Discriminant analysis}

A discriminant analysis was employed to identify the most relevant variables when determining factors and production systems to verify and confirm groups of cattle farmers according to their production characteristics (CORRAR et al., 2009).

The methodology employed in this study may be summarized as follows: after factors were established, the grouping or Cluster analysis was carried out to group farmers in accordance with their characteristics based on the results obtained in the previous analysis. The cluster analysis was conducted using the K-means method, considering four groupings (two, three, four, and five groups). After this analysis, each group was tested by means of discriminant analysis to verify and confirm the ranking of each producer in the group according to their characteristics (Table 1).

Table 1. Grouping analysis results and confirmation of groups by discriminant analysis.

\begin{tabular}{ccccccc}
\hline \multicolumn{7}{c}{ Grouping Analysis } \\
\hline Grouping & System 1 & System 2 & System 3 & System 4 & System 5 & Discriminant Analysis \\
\hline 2 groups & 29 & 12 & & & & $100 \%$ \\
3 groups & 18 & 5 & 18 & & $100 \%$ \\
4 groups & 9 & 10 & 20 & 2 & & $100 \%$ \\
5 groups & 1 & 36 & 2 & 1 & 1 & \\
\hline
\end{tabular}

From these results, the producers were placed in three groups, since the discriminant analysis confirmed the grouping and indicated $100 \%$ accuracy in their formation. The three similar production systems are composed of 18,5 , and 18 producers placed in systems 1,2 , and 3 , respectively, as indicated by the grouping analysis and confirmed by the discriminant analysis (Table 1).

\section{Results and Discussion}

The analysis of factors was employed to determine the most important variables in the productive chain. They are linked to the use of productive resources, land use, productive and zootechnical management, and livestock production characteristics. Initially, this test included all 
variables. The factor analysis used an eigenvalue of 1.5 as cutoff point. The variables with a factor load lower than 0.60 were discarded because they did not prove to be significant for determining the factors.

After the eight-model test, the final model was producedusing 50 variables. Thirteen factors that better depicted property reality were obtained from it. Based on this analysis, the cluster analysis was employed to separate the producers into three groups. Subsequently, the discriminant analysis was applied to confirm the groupings, and it indicated $100 \%$ accuracy in their formation (Table 1 ).

The discriminant analysis identified two discriminant functions for the data, both with $100 \%$ significance. The first function accumulated $61.8 \%$ of data variations, with a canonical correlation coefficient of 0.876 . The second discriminant function found $38.2 \%$ of variations of the model, and it presented a canonical correlation coefficient of 0.819 (Table 2).

Table 2. System Classification According to the Discriminant Function Results.

\begin{tabular}{ccccccccc}
\hline Function & Eigenvalue & $\begin{array}{c}\% \\
\text { Variance }\end{array}$ & $\begin{array}{c}\text { Cumulative } \\
\%\end{array}$ & $\begin{array}{c}\text { Canonical } \\
\text { Correlation }\end{array}$ & $\begin{array}{c}\text { Lambda } \\
\text { Wilks }\end{array}$ & $\begin{array}{c}\text { Chi- } \\
\text { square }\end{array}$ & $\begin{array}{c}\text { Degrees of } \\
\text { Freedom }\end{array}$ & RELEVANCE \\
\hline 1 & 3.292 & 61.8 & 61.8 & .876 & .077 & 82.120 & 26 & .000 \\
2 & 2.033 & 38.2 & 100.0 & .819 & .330 & 35.506 & 12 & .000 \\
\hline
\end{tabular}

The first discriminant function is more strongly associated with factors 3 (productive infrastructure), 5 (operational value), 8 (marketing), 10 (structuring of property), and 11 (animal traceability), as observed by the greater correlation between the discriminant loads of these factors and function 1 .
Conversely, function 2 is more correlated to factors 1 (herd management), 2 (meat quality program), 4 (marketing requirements), 6 (sanitary management), 7 (human factor), 9 (welfare and demand), 12 (remuneration for animal precocity), and 13 (herd sustainability and health), as shown in Table 3.

Table 3. Contribution of Discriminant Loads, Discriminant Weights, and Index of Power to Differentiate Production Systems Through Factors.

\begin{tabular}{lcccc}
\hline \multirow{2}{*}{ Factor } & \multicolumn{2}{c}{ Discriminant Weights } & \multicolumn{2}{c}{ Discriminant Loads } \\
\cline { 2 - 5 } & Function 1 & Function 2 & Function 1 & Function 2 \\
\hline Factor 1 & .252 & .454 & .062 & $.159^{*}$ \\
Factor 2 & .147 & -.402 & .036 & $-.138^{*}$ \\
Factor 3 & -.312 & .122 & $-.074^{*}$ & .041 \\
Factor 4 & -.247 & .835 & -.073 & $.348^{*}$ \\
Factor 5 & .527 & -.071 & $.130^{*}$ & -.025 \\
Factor 6 & .301 & .278 & .073 & $.095^{*}$ \\
Factor 7 & .471 & -.104 & .115 & $-.036^{*}$ \\
Factor 8 & -.730 & -.052 & $-.191^{*}$ & -.019 \\
Factor 9 & -.144 & -.385 & -.035 & $-.132^{*}$ \\
Factor 10 & -.487 & .269 & $-.121^{*}$ & .095 \\
Factor 11 & 1.091 & .406 & $.480^{*}$ & .253 \\
Factor 12 & -.294 & .420 & -.073 & $.147^{*}$ \\
Factor 13 & .385 & -.837 & .118 & $-.362^{*}$ \\
\hline
\end{tabular}

(*) indicates with which function the variable correlates the most. 
The grouping analysis (Cluster) and the three similar production systems are composed of discriminant analysis indicated that that the 18, 5, and 18 producers allocated in systems 1, 2, producers would be plotted in three groups. The and 3, respectively, as shown in Figure 1.

Figure 1. Illustration of the three Production systems in Northwest Paraná per characteristics that are similar and/or different between each other.

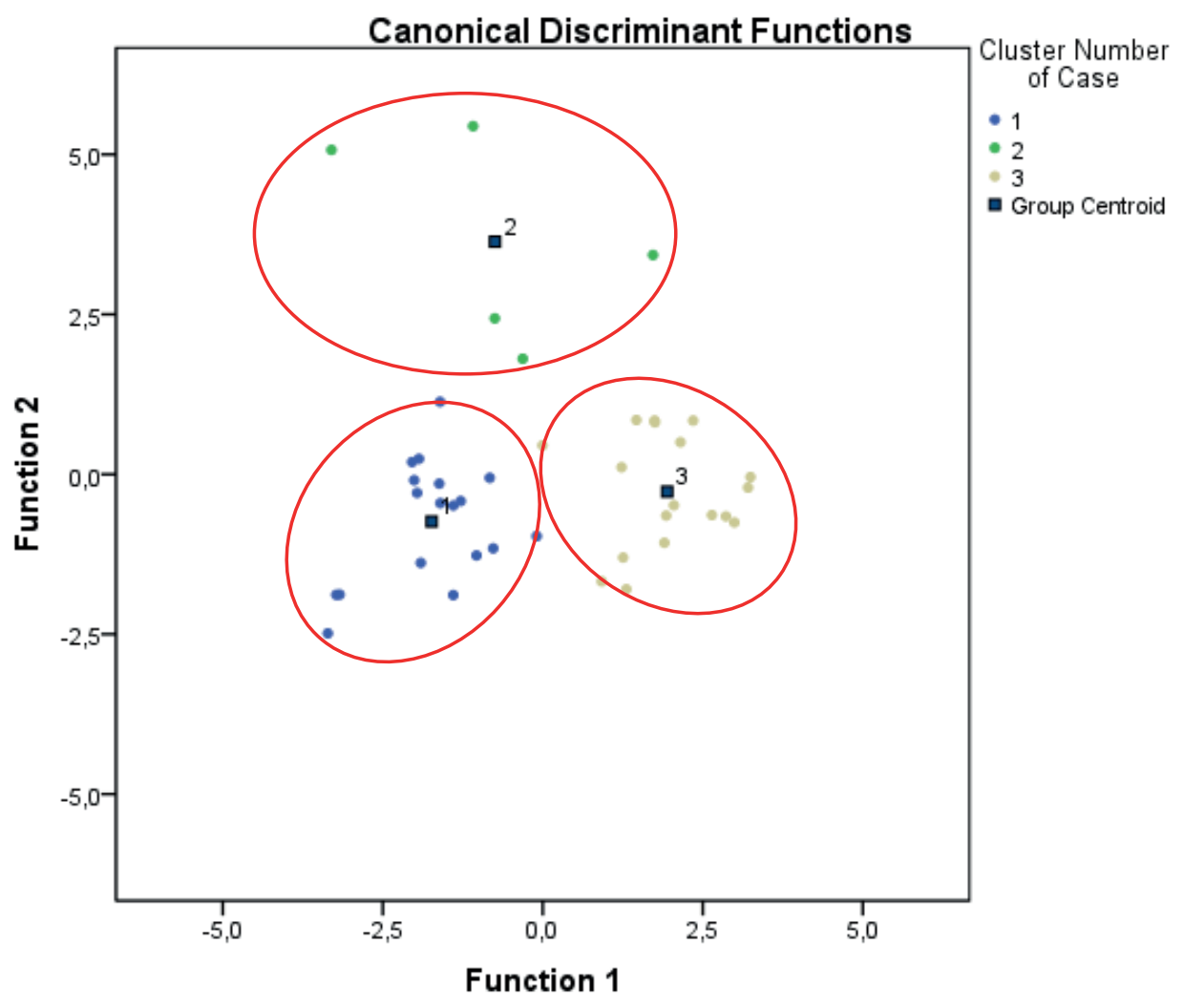

This differs from studies done by Aleixo et al. (2007), Andrade et al. (2007), Lopes Junior et al. (2012), Bezerra et al. (2013), Neves et al. (2015), and Cyrne et al. (2015), presenting groups containing 4, $16,2,4,4,5$, and 2 systems, respectively.

The producers composing system 2 have positive, high values for function 2 , but they were more strongly related to factors $1,2,4,6,7,9,12$, and 13 (Table 3). Upon analyzing discriminant function 1 , it was more related to factors $3,5,8,10$, and 11 , and the producers were more dispersed, as shown in Figure 1. The second system represents more qualified producers who perform the activity more professionally, especially regarding the marketing process and aspects related to meat quality and environmental management. They aim to meet market demand and have turned their properties into rural companies.

System 3 focuses on the lower quadrant of the territorial map, i.e., it concentrates high values for discriminant function 1 , which is linked to factors $3,5,8,10$, and 11 , but low values compared to discriminant function 2 . This function is related to factors 1, 2, 4, 6, 7, 9, 12, and 13 (Figure 1). These results show that this group has mixed characteristics compared to the other two systems. This may 
be regarded as a system formed by producers in transition, i.e., it is composed of producers that present characteristics similar to system 1, which is a group of more traditional producers; but how producers seek to improve their activity results also fit the characteristics of production system 2, which is a group of producers involved with professional livestock farming.

In general, the farmers classified in system 1 are concentrated in the lower left quadrant of the territorial map. They present negative values for both discriminant functions. This system represents the farmers who still perform the activity in a more traditional way, with less control, i.e., more extensively (Table 3 and Figure 1).

Nonetheless, in a study conducted by Simões et al. (2006), three systems were found as well. In this study, the authors compared the economic efficiency of breeding, rearing, and fattening systems. Diverging from this study, which aimed to identify the different production systems in the region and analyze the property gains, the fattening system presented the highest risk of yielding low profits. System 2 was superior to the others because it implemented technologies in the properties to meet demands. Consequently, it increased the remuneration of the product offered.

Figure 1 shows farmer placement per the characteristics that make them different, which are related to the variables grouped into factors. After that, the groups were classified perthe discriminant function. According to the load that a member has in a certain variable (function), it is placed in a specific area in the function graph, in which each group is represented by a specific color.

Finally, it is possible to visualize that group 1 is composed of 18 members, group 2 is composed of 5 producers, and the third group is composed of 18 producers per the characteristics that best classified them within each group.

\section{Conclusions}

This study identified three production systems in Northwest Paraná. The three groups have different production techniques, but similarities are shared within these groups. System 2 was superior to systems 1 and 3 , since it met quality demands for marketing better; thus, it received a better bonus.

\section{Acknowledgements}

Universidade Estadual de Maringá - UEM, Campus Regional de Umuarama.

Sociedade Rural de Umuarama.

Livestock farmers in the region.

\section{References}

ALEIXO, S. S.; SOUZA, J. G. de; FERRAUDO, A. S. Técnicas de análise multivariada na determinação de grupos homogêneos de produtores de leite. Revista Brasileira de Zootecnia, Viçosa, MG, v. 36, n. 6, p. 2168 2175, 2007 Suplemento.

ANDRADE, M. L.; MIELITZ NETTO, C. G. A.; NABINGER, C.; SANGUINÉ, E.; WAQUIL, P. D.; SCHNEIDER, S. Caracterização socioeconômica e produtiva da bovinocultura de corte no estado do Rio Grande do Sul. Revista Estudo e Debate, Lajeado, v. 14, n. 2, p. 95-125, 2007.

BEZERRA, L. R.; ARAÚJO, M. J. de; MARQUES, C. A. T.; TORREÃO, J. N. da C.; VAZ, R. R.; OLIVEIRA NETO, C. B. de. Caracterização de propriedades agrícolas para pecuária de corte. Comunicata Scientiae, Logroño, v. 4, n. 1, p. 75-84, 2013.

CORRAR, L. J.; PAULO, E.; DIAS FILHO, J. M. Análise multivariada: para os cursos de Administração, Ciências Contábeis e Economia. São Paulo: Atlas, 2009. n. $2,568 \mathrm{p}$.

CYRNE, C. C. S.; REMPEL, C.; HAETINGER, C.; BORTOLI, J. O (não) uso de indicadores de gestão em propriedades leiteiras na Galícia - Espanha. Holos, Natal, ano 31, v. 5, p. 307-321, 2015.

DeMEU, A. A.; LOPES, M. A.; BARBOSA, F. A. Resultados econômicos da terminação de bovinos de corte em confinamento no município de Sete Lagoas MG. Boletim de Indústria Animal, Nova Odessa, v. 69, n. 1, p. 13-22, jan./jun. 2012. 
FERNANDES, G. A.; FERNANDES, F. F. D.; MOUSQUER, C. J.; OLIVEIRA, E. B. de; CASTRO, W. J. R. de; SILVA FILHO, A. S. Produção de novilhos superprecoce a pasto. Uma revisão. Revista Brasileira de Higiene e Sanidade Animal, Fortaleza, v. 9, n. 3, p. 553579, 2015.

FERRAZZA, R. A.; LOPES, M. A.; SANTOS, T. K. Análise de rentabilidade da terminação de bovinos de corte em confinamento: um estudo de caso no ano de 2009 na região oeste de Minas Gerais, Brasil. Archivos Latinoamericanos de Producción Animal, Maracay, v. 23, n. 1, p. 37-47, 2015.

FERRAZZA, R. A.; SCHÜLLER, M. C.; LOPES, M. A.; LAGE, L. A. Rastreabilidade bovina na região centrosul do estado de Mato Grosso: aspectos econômicos, técnicos e conceituais. Boletim de Indústria Animal, Nova Odessa, v. 70, n. 2, p. 110-118, 2013.

HOFFMANN, A.; MORAES, E. H. B. K. de; MOUSQUER, C. J.; SIMIONI, T. A.; GOMES, F. J.; FERREIRA, V. B.; SILVA, H. M. da. Produção de bovinos de corte no sistema de pasto-suplemento no período seco. Nativa, Sinop, v. 2, n. 2, p. 119-130, abr./ jun. 2014.

INSTITUTO BRASILEIRO DE GEOGRAFIA E ESTATÍSTICA - IBGE. Notícias: PPM: rebanho bovino alcança a marca recorde de 215,2 milhões de cabeças, mas produção de leite cai 0,4\%. Rio de Janeiro: Agência de notícias, 2016.

LOPES JUNIOR, J. F.; RAMOS, C. E. C. de O.; SANTOS, G. T. dos; GRANDE, P. A.; DAMASCENO, J. C.; MASSUDA, E. M. Análise das práticas de produtores em sistemas de produção leiteiros e seus resultados na produção e qualidade do leite. Semina: Ciências Agrárias, Londrina, v. 33, n. 3, p. 1199-1208, maio/jun. 2012.
MILONE, G. Estatística geral e aplicada. São Paulo: Thomson, 2004. 484 p.

NEVES, B. M. C.; VEloso, F. P.; MOTA, A. L. A. A.; FERREIRA NETO, J. S.; BAUMGARTEN, K. D.; FERREIRA, F.; GONÇALVES, V. S. P. Caracterização produtiva e aspectos sanitários relacionados à bovinocultura em Santa Catarina. In: ENCONTRO NACIONAL DE EPIDEMIOLOGIA VETERINÁRIA, 2., 2015, Brasília. Anais... Brasília: O Biológico, 2015. v. 77 p. $40-40$.

PORTAL BRASIL. Rebanho bovino alcança 215,2 milhões de cabeças em 2015. Economia e emprego. Brasília: Portal Brasileiro de Dados Abertos, 2016.

SECRETARIA DE ESTADO DA AGRICULTURA E DO ABASTECIMENTO/DEPARTAMENTO DE ECONOMIA RURAL - SEAB/DERAL. Análise da conjuntura agropecuária: pecuária de corte ano 2014/2015. Curitiba: SEAB/DERAL, 2015.

SIMÕES, A. R. P.; MOURA, A. D. de; ROCHA, D. T. da. Avaliação econômica comparativa de sistemas de produção de gado de corte sob condições de risco no Mato Grosso do Sul. Revista de Economia e Agronegócio, Viçosa, MG, v. 5, n. 1, p. 51-72, 2006.

SOTOMAIOR, C. S.; CARLI, L. M. de; TANGLEICA, L.; KAIBER, B. K.; SOUZA, F. P. de. Identificação de ovinos e caprinos resistentes e susceptíveis aos helmintos gastrintestinais. Revista Acadêmica: Ciência Animal, Curitiba, v. 5, n. 4, p. 397-412, out./dez. 2007.

STEVENSON, W. J. Estatística aplicadaàadministração. São Paulo: Harbra, 1981. 498 p. 